\title{
TERAPI KOMPLEMENTER AKUPUNTUR BAGI PENDERITA SINDROMA TEROWONGAN KARPAL
}

\author{
Jihan Nur Pratiwi*, Khoirun Nisa \\ Fakultas Kedokteran, Universitas Lampung, Jl. Prof. Dr. Ir. Sumantri Brojonegoro No.1, Gedong Meneng, Kec. \\ Rajabasa, Kota Bandar Lampung, Lampung, Indonesia 35145 \\ *jnurpratiwi@gmail.com (+6281366441335)
}

\begin{abstract}
ABSTRAK
Sindroma Terowongan Karpal (Carpal Tunnel Syndrome atau CTS) adalah kondisi kompresi saraf medianus pada terowongan karpal sehingga muncul gejala klinis berupa kekakuan, paresthesia, dan nyeri. Beberapa intervensi perawatan baik konservatif dan bedah diusulkan untuk pengobatan CTS. Intervensi konservatif termasuk bebat, injeksi steroid lokal, carpal tunnel release, steroid oral atau ketoprofen phonophoresis, efektif pada pasien dengan gejala ringan sampai sedang. Sementara pembedahan disarankan jika intervensi konservatif gagal. Di antara intervensi tersebut, akupuntur telah mendapat perhatian khusus. Akupuntur adalah terapi komplementer yang telah lama digunakan pada perawatan medis di Cina. Literature review ini bertujuan untuk menjelaskan efektifitas akupuntur dalam pengelolaan CTS mulai dari gejala ringan hingga sedang. Metode yang digunakan dalam artikel ini adalah penelusuran artikel melalui database NCBI. Tahun penerbitan pustaka adalah dari tahun 2004 hingga 2017 dengan 22 sumber pustaka. Artikel yang dikumpulkan terkait dengan stimulasi terapi akupuntur terhadap perubahan dalam pemrosesan otak pada respon limbik yang terkoordinasi, efek anti-inflamasi, dan modulator imun. Hasil dari sintesa 14 artikel yang telah ditemukan, terdapat pengaruh terapi komplementer akupuntur pada peningkatan regenerasi saraf dan kinerja fungsional pada penderita Sindroma Terowongan Karpal.
\end{abstract}

Kata kunci: akupuntur, terapi komplementer, sindroma terowongan karpal

\section{ACUPUNCTURE COMPLEMENTARY THERAPY FOR PEOPLE WITH CARPAL TUNNEL SYNDROME}

\begin{abstract}
Carpal Tunnel Syndrome (CTS) is a condition of median nerve compression in the carpal tunnel so that clinical symptoms appear in the form of stiffness, paresthesia, and pain. Several conservative and surgical treatment interventions are proposed for the treatment of CTS. Conservative interventions including bebat, local steroid injection, carpal tunnel release, oral steroids or ketoprofen phonophoresis, are effective in patients with mild to moderate symptoms. While surgery is recommended if conservative intervention fails. Among these interventions, acupuncture has received special attention. Acupuncture is a complementary therapy that has long been used in medical care in China. This literature review aims to explain the effectiveness of acupuncture in the management of CTS ranging from mild to moderate symptoms. The method used in this article is article searching through the NCBI database. Library publication year is from 2004 to 2017 with 22 library sources. The articles collected are related to the stimulation of acupuncture therapy for changes in brain processing in coordinated limbic responses, anti-inflammatory effects, and immune modulators. The results of the synthesis of 14 articles that have been found, there is the effect of acupuncture complementary therapy on increased nerve regeneration and functional performance in patients with carpal tunnel syndrome.
\end{abstract}

Keywords: acupuncture, complementer therapy, carpal tunnel syndrome 


\section{PENDAHULUAN}

Sindroma Terowongan Karpal atau Carpal Tunnel Syndrome (CTS) merupakan sindroma yang muncul diakibatkan oleh saraf medianus tertekan di dalam Carpal Tunnel (terowongan karpal) pada pergelangan tangan, saat nervus melewati terowongan tersebut dari lengan bawah ke tangan (Jagga \& Lehri, 2011). Sindroma ini dapat disebabkan oleh penyempitan pada radius distal yang mengakibatkan kompresi saraf medianus di bawah retinakulum volar. Kebanyakan sindroma ini bersifat idiopatik. Penderita mengalami keluhan berupa kekakuan, mati rasa (paresthesia), dan nyeri terutama saat melakukan pekerjaan yang banyak menggunakan tangan (DeJong,. 2012).

Penderita dengan gejala CTS terbanyak di Indonesia merupakan pekerja pemetik teh. Angka kejadian CTS pada pekerja pemetik teh, berdasarkan usia, meningkat setelah umur 40 tahun dan angka kejadian CTS tertinggi terjadi antara umur 50-59 tahun (Bahrudin et al, 2015). National Health Interview Study (NIHS) tahun 2010 mencatat bahwa CTS lebih sering mengenai wanita daripada pria dengan usia berkisar 25-64 tahun, prevalensi tertinggi pada wanita usia $>55$ tahun, biasanya antara 4060 tahun. Prevalensi CTS dalam populasi umum telah diperkirakan 5\% untuk wanita dan $0,6 \%$ untuk laki-laki. Sindroma terowongan karpal adalah jenis neuropati jebakan yang paling sering ditemui. Sindroma tersebut unilateral pada $42 \%$ kasus (29\% kanan, 13\% kiri) dan 58\% bilateral (Tana et al., 2004)

Selain itu penelitian Tana et al. menyimpulkan bahwa terdapat sejumlah tenaga kerja yang menderita CTS di beberapa perusahaan garmen di Jakarta yaitu sebanyak 20,3\% responden dengan besar gerakan biomekanik berulang sesaat yang tinggi pada tangan dan pergelangan tangan kanan $74,1 \%$, serta pada tangan kiri 65,5\%. Pekerja perempuan dengan CTS lebih tinggi secara bermakna dibandingkan dengan pekerja laki-laki. Tidak terdapat perbedaan antara peningkatan umur, pendidikan, masa kerja, jam kerja serta tekanan biomekanik berulang sesaat terhadap peningkatan terjadinya CTS (Tana et al., 2004)

Dalam mengatasi CTS, terdapat terapi konservatif dan terapi bedah. Dimana terapi konservatif termasuk bebat pergelangan tangan, injeksi steroid lokal, steroid oral atau ketoprofen phonophoresis, carpal tunnel release, fisioterapi berupa peregangan lengan dan pergelangan tangan. Terapi bedah dilakukan jika terapi konservatif tidak lagi menimbulkan perbaikan American (Academy of Orthopaedic Surgeons, 2016). Di antara intervensi yang ada, akupuntur telah mendapat perhatian khusus pada bidang medis sebagai terapi komplementer untuk mengatasi CTS dengan gejala ringan hingga sedang (Franklin \& Friedman, 2015).

Menurut buku pedoman praktis belajar akupuntur, akupuntur berasal dari kata Latin. Acus yang artinya jarum dan Punctur yang artinya menusuk, jadi akupuntur berarti "menusuk dengan jarum" (Permadi \& Djuharto, 2004). Akupuntur adalah modalitas terapeutik invasif minimal yang berasal dari Cina 2000 tahun yang lalu sebagai komponen pengobatan Tiongkok tradisional (Kaptchuk, 2004). Sementara terapi akupuntur berakar pada ritual praktik yang kompleks, prosedur jarum akupuntur, terutama ketika ditambah dengan stimulasi jarum listrik, tumpang tindih secara signifikan dengan banyak terapi neuromodulator perifer konvensional yang telah menghasilkan hasil yang signifikan sebagai 'electroceuticals' yang menargetkan reseptor saraf tepi (Langevin et al., 2015)

Pada konferensi yang diselenggarakan untuk mengevaluasi secara kritis penelitian mengenai akupuntur yakni konsensus NIH 1997, akupuntur disarakan sebagai terapi tambahan yang menjanjikan untuk CTS 
(Kaptchuk, 2004). Sejak saat itu, berbagai uji coba terkontrol secara acak telah dilakukan dan diantaranya menemukan peningkatan konduksi saraf serta mengurangi keparahan gejala CTS setelah mendapatkan terapi akupuntur (Famm et al., 2013).

\section{METODE}

Metode yang digunakan dalam penulisan artikel ini adalah literature review. Sumber pustaka yang digunakan dalam artikel ini melibatkan 22 pustaka baik yang berasal dari buku, jurnal nasional atau internasional, maupun website. Penelusuran sumber pustaka dalam artikel ini melalui database NCBI dengan kata kunci Acupuncture, Complementer Therapy, Carpal Tunnel Syndrome, Nerve Regeneration. Pemilihan artikel sumber pustaka dilakukan dengan melakukan peninjauan pada judul dan abstrak yaitu membahas tentang pengaruh terapi komplementer akupuntur pada penderita sindroma terowongan karpal. Tahun penerbitan sumber pustaka dalam penulisan artikel ini adalah 2004 hingga tahun 2017.

\section{HASIL}

Belakangan ini akupuntur telah mendapat perhatian khusus dalam penatalaksanaan nyeri dalam dunia medis. Efektifitas akupuntur sebagai terapi komplementer pada CTS telah dipelajari dalam beberapa penelitian. Salah satunya pada penelitian Hadianfard et al. pasien pada kelompok kontrol diberikan bebat pergelangan tangan dan ibuprofen, sementara kelompok intervensi diberikan bebat pergelangan tangan dan akupuntur konvensional. Didapatkan hasil dalam parameter elektrofisiologis, DSL (Distal Sensory Latency) dan NCV (Nerve Conduction Velocity) menurun pada kedua kelompok $(\mathrm{p}<0,001)$ dan mendukung kelompok akupuntur yaitu $(\mathrm{p}<0,001)$ pada DSL dan $(\mathrm{p}=0,002)$ pada NCV, sementara pada DML (Distal Motoric Latency) kedua kelompok terdapat penurunan tetapi tidak terdapat perbedaan yang signifikan diantara kedua kelompok ( $>00,05)$ (Hadianfard et al., 2015)

Partisipan yang mendapatkan bebat pergelangan tangan dan terapi akupuntur memiliki peningkatan pengurangan nyeri yang lebih besar dibandingkan pasien yang mendapatkan bebat pergelangan tangan dan ibuprofen. Penurunan rasa kebas dan kesemutan di malam hari membaik pada kelompok intervensi. Frekuensi terbangun karena sakit atau kesemutan dan mati rasa pada malam hari juga berkurang pada penerima terapi akupuntur. Selain itu terjadi peningkatan parameter elektrodiagnostik (kecuali DML) dibandingkan dengan kelompok yang menerima anti-inflamasi. Kinerja fungsional pun mengalami peningkatan namun perbedaannya tidak signifikan secara statistik pada item fungsional lainnya (Hadianfard et al., 2015).

Pada penelitian lain yang dilakukan oleh Saeid et al. partisipan dibagi ke dalam kelompok kontrol berupa bebat pergelangan tangan, vitamin $B_{1}$ dan $B_{6}$, dan sham akupuntur dalam 4 minggu, serta kelompok intervensi berupa bebat pergelangan tangan dan akupuntur 8 sesi dalam 4 minggu. Tujuan dari penelitian ini adalah untuk menilai efek jangka pendek akupuntur sebagai terapi komplementer dalam CTS dengan gejala ringan hingga sedang. Hasil menunjukan partisipan kelompok intervensi secara signifikan mengalami perubahan yang lebih baik pada gejala klinis CTS ( $<<0.001)$ dinilai menggunakan Global Symptom Score (GSS). Sementara pada parameter elektrofisiologi, NCV menunjukan perubahan lebih baik $(\mathrm{p}=0.02)$ pada kelompok intervensi, namun tidak menunjukan perubahan signifikan antara kedua kelompok pada DSL dan DML (p>0.05) (Saeid et al., 2012)

Penelitian yang dilakukan oleh McCaig et al. menunjukan bahwa akupuntur terutama elektroakupuntur dapat meregenerasi saraf dengan meningkatkan konsentrasi kalsium, 
menyebabkan aktifasi pertumbuhan dan perbaikan saraf (McCaig et al,.2004)

\section{PEMBAHASAN}

Secara anatomis, canalis carpi (carpal tunnel) berada di dalam dasar pergelangan tangan. Sembilan ruas tendon fleksor dan N. Medianus berjalan di dalam canalis carpi yang dikelilingi dan dibentuk oleh tiga sisi dari tulang-tulang carpal. Nervus dan tendon memberikan fungsi, sensibilitas, dan pergerakan pada jari-jari tangan. Pada terowongan carpal, N. Medianus bercabang menjadi komponen radial dan ulnar. Komponen radial dari N. Medianus akan menjadi cabang sensorik pada permukaan palmar jari-jari pertama dan kedua serta cabang motorik M. Abduktor Pollicis brevis, M. Opponens Pollicis, dan bagian atas dari M. Flexor Pollicis brevis. (Pecina et al., 2010).

Tertekannya N. Medianus dapat disebabkan oleh berkurangnya ukuran canalis carpi, membesarnya ukuran alat yang masuk di dalamnya (pembengkakan jaringan lubrikasi pada tendon-tendon fleksor) atau keduanya. Gerakan fleksi dengan sudut 90 derajat dapat mengecilkan ukuran canalis carpi. Penekanan terhadap N. Medianus yang menyebabkannya semakin masuk di dalam ligamentum carpi transversum dapat menyebabkan atrofi eminensia thenar, kelemahan pada M. Flexor Pollicis brevis, M. Abductor Pollicis brevis, M. Opponens Pollicis yang diikuti dengan hilangnya kemampuan sensorik ligametum carpi transversum yang dipersarafi oleh bagian distal N. Medianus. Cabang sensorik superfisial dari N. Medianus yang mempercabangkan persarafan proksimal ligamentum carpi transversum yang berlanjut mempersarafi bagian telapak tangan dan jari jempol (Pecina et al., 2010).

Kasus CTS sebagian besar disebabkan karena kompresi pada ruang terowongan karpal. Susunan tulang karpal dan ligamen karpal tranversum membentuk carpal tunnel (terowongan karpal) yang mana pada ruang tersebut diisi oleh sembilan flexor tendon dan saraf medianus. Sebelum masuk ke area carpal tunnel, cabang yang mensarafi area palmar cutaneus membawa serabut sensorik otot thenar. Setelah keluar dari area carpal tunnel, cabang dari otot thenar menginervasi M. Abduktor Pollicis brevis, M. Opponens Pollicis, dan M. Lumbrical I serta II. Selain itu juga mensarafi M. Flexor Pollicis brevis. Pada cabang yang lain mensarafi jari I, II, III dan setengah jari IV. Akibatnya timbul gangguan motorik dan sensorik pada bagian palmar, falang I, II, III dan falang lateral IV (Aroori \& Spence, 2008).

Beberapa teori menjelaskan gejala dan proses terperangkapnya saraf medianus. Teori-teori tersebut yaitu kompresi mekanik, insufisiensi mikrovaskular, dan vibrasi. Kompresi mekanik menjelaskan faktor penyebab terjadinya CTS karena strain, penggunaan tangan berlebihan, dan pekerjaan yang berulang-ulang pada pergelangan tangan yang menyebabkan terjadinya kompresi atau penekanan pada saraf medianus sehingga perjalanan saraf ke jari I-IV terhambat. Sedangkan pada teori insufisiensi mikrovaskular berpendapat bahwa berkurangnya asupan darah yang terdiri dari oksigen dan nutrisi untuk saraf menyebabkan kemampuan transmisi impuls saraf menurun. Karakteristik yang akan dirasakan adalah tersengat, mati rasa, dan nyeri akut. Teori terakhir yaitu teori vibrasi, menyebutkan gejala CTS dapat menghasilkan efek jangka panjang akibat penggunaaan alat yang menimbulkan vibrasi pada saraf medianus di terowongan karpal (Aroori \& Spence, 2008).

Menurut Ibrahim et al. (2012) tanda dan gejala CTS dapat diklasifikasikan menjadi tiga tahap yaitu:

a. Tahap pertama, pasien mengalami gangguan tidur pada malam hari terasa kebas dan bengkak pada tangan. Beberapa merasakan nyeri berat yang terasa dari pergelangan sampai bahu seperti tertusuk yang menimbulkan rasa 
tidak nyaman pada pergelangan tangan sampai jarijari (brachialgia paraesthetica nocturna). Saat dilakukan flick sign akan memprovokasi keluhan. Selain itu, di pagi hari terasa kaku pada jari-jari.

b. Tahap kedua, gejala muncul sepanjang hari terutama saat melakukan aktivitas statis dalam waktu yang lama atau pekerjaaan berulang ulang pada pergelanagan tangan. Sehingga benda yang ada dalam genggaman akan jatuh karena tidak dapat merasakan lagi akibat motor deficit.

c. Pada tahap akhir ini, muncul atropi pada otot thenar dan respon saraf medianus menjadi lambat akibat kompresi pada carpal tunnel. Pada fase ini sensoriknya mulai berkurang, terasa sakit pada otot thenar kompresi semakin berat, kelemahan dan atropi pada M. Abduktor Pollicis.

Berbagai tes klinis seperti Tinel sign, Phalen test, dan kompresi terowongan karpal dapat membantu menegakkan diagnosis sindroma ini. Sementara diagnostik konfirmasi dapat digunakan elektrodiagnostik. Elektrodiagnostik merupakan metode paling sensitif untuk diagnosis, menilai tingkat keparahan, dan evaluasi masalah lain yang muncul. Pemeriksaan radiologi jarang digunakan dan tidak memberi respon terhadap pengobatan konservatif atau memberikan gambaran normal pada konduksi saraf. Terapi lini pertama yaitu terapi konservatif, berdasarkan Work-Related Carpal Tunnel Syndrome Diagnosis and Treatment Guideline, terapi konservatif yaitu bebat pergelangan tangan, injeksi steroid lokal, dan latihan peregangan lengan dan pergelangan tangan (American Academy of Orthopaedic Surgeons, 2016).

Sedangkan menurut American Association or Orthopedic Surgeon (AOOS) yaitu bebat pergelangan tangan, injeksi steroid lokal, steroid oral, ketoprofen phonophoresis, dan carpal tunnel release. Terapi bedah direkomendasikan jika terapi konservatif tidak mengalami perbaikan dalam 6-8 minggu.

Injeksi steroid pada terowongan karpal efektif untuk jangka pendek dengan kesembuhan hingga $80 \%$ dalam sewaktu. Terapi bedah hanya direkomendasikan pada $40 \%$ kasus, sementara penyembuhan paska operasi dari teknik konservatif berlangsung lambat. Teknik endoskopi dapat memperpendek masa pemulihan namun tidak selalu tersedia. Komplikasi meningkat $10 \%$ pada bedah kasus terowongan karpal termasuk kegagalan untuk pulih dari gejala atau gejala kembali muncul (Banner \& Hudson, 2005).

Hasil penelitian terbaru mengenai akupuntur didapatkan bahwa akupuntur merupakan terapi yang relatif tidak berbahaya dan dapat ditoleransi, sebagai terapi komplementer untuk mengatasi CTS (Ibrahim, 2012). Akupunktur adalah terapi dengan cara menusukan jarum pada daerah di permukaan tubuh atau suatu cara pengobatan yang memanfaatkan rangsangan pada titik-titik akupunktur (Acupuncture points/acupoints) (Banner \& Hudson, 2005).

Titik akupunktur dianggap sebagai komponen penting dari terapi akupunktur untuk diagnosis dan perawatan. Sayangnya, meskipun banyak penelitian dilakukan untuk menentukan pentingnya titik akupunktur dari perspektif anatomi atau histologis, tidak ada bukti yang jelas tentang titik yang sesuai. Di sisi lain, beberapa karakteristik fisiologis dari titik akupunktur seperti teraba lembut dan keras dianggap sebagai sensitisasi nosiseptor dan fungsi efektornya setidaknya sebagian. Buku teks tradisional Tiongkok menggambarkan titik ah-shi, titik yang dipukul oleh jarum yang dimasukkan untuk membangkitkan reaksi vokal terhadap rasa sakit, sebagai jenis titik akupunktur. Artinya, kelembutan adalah salah satu 
karakter fisiologis dari titik akupunktur (Kenji \& Kaoru, 2014).

Akupuntur mempengaruhi patologi dan simptomatologi CTS melalui mekanisme perifer dan sentral. Karena CTS disebabkan oleh neuropatologi iskemik, kemampuan akupuntur untuk menginduksi peningkatan aliran darah baik ke dalam maupun ke permukaan dapat meningkatkan sirkulasi mikro ke saraf median yang tertekan pada terowongan karpal (Napadow, 2007).

Proses pada perifer dalam akupuntur yakni induksi perubahan pada jaringan yang ditembus ketika jarum dimasukkan ke kulit. Hal ini dapat memperbaiki fungsi jaringan melalui vasodilatasi di kulit disebabkan oleh refleksi akson, yang menyebabkan reaksi inflamasi langsung. Vasodilatasi ini dapat disebabkan oleh pelepasan Calcitonin Gene-related Peptide (CGRP). Pelepasan lokal dari beta-Endorphins dapat bertanggung jawab untuk efek analgesik jangka pendek, dimana neuropeptida terinduksi mengeluarkan sitokin anti inflamasi dapat menjadi derifat dari limfosit dan aktifasi sel sekunder seperti makrofag. Pada jaringan permukaan, level sebenernya dari CGRP sangat penting. Terutama CGRP telah terbukti sebagai pro-inflamator namun pada dosis rendah ia dapat berpotensi sebagai anti-inflamator. ${ }^{18}$

Salah satu mekanisme yang menjelaskan penghilang langsung rasa nyeri dengan akupuntur yaitu stimulasi pengkondisian nyeri disebut juga Diffuse Noxious Inhibitory Controls (DNIC). Menurut DNIC, stimulus berbahaya yang diterapkan pada bagian tubuh mana pun dapat menyebabkan penghilangan segera terhadap transmisi nyeri atau dideskripsikan sebagai pain inhibits pain. Noksius menstimulasi aktifasi ujung dari nosiseptif $\mathrm{C}$ dan serat saraf A delta, yang membawa sinyal ke neuron pada cornu dorsal pada medula spinalis. Oleh karena itu, input DNIC aferen berasal dari nosiseptor responsif terhadap rangsangan mekanik, termal, dan kimia. Reseptor ini didistribusikan di kulit, otot, dan lemak ke seluruh tubuh. Karakteristik input aferen ini sangat mirip dengan reseptor polimodal (PMR) (Zijlstra, 2004).

Mekanisme akupuntur dalam memperbaiki gejala yang ditimbulkan CTS secara sentral sampai saat ini belum dapat dipahami secara akurat, namun penelitian yang ada saat ini menunjukan adanya efektivitas metode akupuntur dalam pengelolaan CTS. Diantaranya yaitu studi dengan pencitraan resonansi magnetik fungsional (MRI) menunjukan bahwa stimulasi akupuntur menyebabkan perubahan dalam pemrosesan otak pada respon limbik yang terkoordinasi. Sistem limbik yang berperan antara lain amigdala dan hipotalamus (Napadow, 2007).

Amigdala penting dalam memproses emosi terutama ketakutan dan pertahanan. Amigdala diketahui deaktif pada CTS sebagai respon dari akupuntur. Fungsi akupuntur memperbaiki komponen dari nyeri dengan mendeaktifasi sensitifitas hiperaktif amigdala. Deaktifasi jangka pendek penting dalam amigdala menginisiasi progresif normal aktifitas neuroplastisitas. Sementara Hipotalamus merupakan komponen penting dalam kerja autonomik sentral. Melalui jalur kolinergik anti-inflamasi, aktifitas autonomik dari hipotalamus dapat menghambat inflamasi. Akupuntur dapat menurunkan regulasi respon inflamasi dengan menyeimbangkan simpatovagal. Akupuntur memodulasi respon simpatik lokal menuju lesi CTS melalui modulasi sentral aktifitas hipotalamus (Napadow, 2007).

Penusukan jarum pada titik-titik akupuntur dapat memberikan kesinambungan sementara antara saraf perifer yang rusak dengan saraf pusat, dengan demikian memastikan suplai nutrisi antara badan sel saraf dan mempertahankan faktor neurotropik, karena kekurangan nutrisi dapat menyebabkan neuron apoptosis. Proses ini juga dapat mempersingkat perbaikan sel saraf yang mengalami 
kerusakan dan dapat pula menjadi dasar untuk perbaikan regenerasi saraf. Namun ditemukan perbedaan antara efek terhadap motorik dan sensorik, dimana akupuntur memiliki sedikit efek teradap konduksi saraf sensorik. Pada konduksi saraf motorik dapat membaik dalam 30 hari sementara pada konduksi saraf sensorik membutuhkan waktu yang lebih lama. Hal ini berkaitan dengan regenerasi akson neuron motorik setelah saraf perifer cidera didominasi oleh cabang otot (muscular branches) atau dikenal sebagai prioritas reinervasi cabang otot (Guan et al., 2015)

Efek samping akupuntur pada CTS antara lain terjadinya pembengkakan dan rasa sakit di tangan akibat penusukan jarum akupuntur (Kenji \& Kaoru, 2014) Bukti yang tersedia dari survei prospektif skala besar menunjukkan bahwa terapi akupunktur aman. Efek samping serius dan kematian yang disebabkan oleh terapi akupunktur jarang terjadi (Napadow, 2007).

\section{SIMPULAN}

Terapi akupuntur berpengaruh terhadap sindroma terowongan karpal terutama dalam meningkatkan konduksi saraf, memperbaiki kinerja fungsional, dan regenerasi saraf. Sehingga akupuntur dapat menjadi alternatif terapi komplementer dalam mengatasi gejala klinis yang ditimbulkan sindroma terowongan karpal.

\section{DAFTAR PUSTAKA}

American Academy of Orthopaedic Surgeons. (2016). Management of Carpal Tunnel Syndrome EvidenceBased Clinical Practice Guideline. www.aaos.org/ctsguideline. Published February 29

Aroori, S., Spence, R.A.J. (2008). Carpal tunnel syndrome. The Ulster Medical Society.; Vol 77. Page 1-17.

Bahrudin, M., Resi, L.P.P., Hafif, F.A.S. (2015). Hubungan masa kerja dengan kejadian CTS pada pekerja pemetik daun teh. Jurnal Universitas Muhammadiyah Malang. Volume 11 no 2.

Banner, R. and Hudson E. W. (2005). Case report: acupuncture for carpal tunnel syndrome. Ultrasound assessment of adjunct therapy. Can Fam Physician. Mar; 47: 547-9.

DeJong, R.N. (2012). The neurologic examination 5 th ed. revised by A.F. Haerer. Philadelphia: Lippincott Williams and Wilkins. Hlm. 1015-16.

Famm, K., Litt, B., Tracey, K.J., Boyden, E.S., Slaoui, M. (2013). Drug discovery: a jump-start for electroceuticals. Nature.; 496: 159-61

Franklin, G.M. \& Friedman, A.S. (2015). Work-related carpal tunnel syndrome. Physical Medicine and Rehabilitation Clinics of North America; 26(3), 523-37.

doi:10.1016/j.pmr.2015.04.003

Guan, H., Jing-wen, R., Yuan-shan, Z., Xin, Z., Ying, D., and Guang-hui, $\quad Z$. (2015). Improvement in acupoint selection for acupuncture of nerves surrounding the injury site: electroacupuncture with governor vessel with local meridian acupoints Neural Regen Res. Jan; 10(1): 128-135.

Hadianfard, M., Bazrafshan, E., Momeninejad, H., Jahani, N. (2015). Efficacies of acupuncture and antiinflammatory treatment for carpal tunnel syndrome. Journal of Acupuncture and Meridian Studies.; 8(5), 229-235 doi:10.1016/j.jams.2014.11.005.

Harris, R.E., Napadow, V., et al. (2015). Manual and electrical needle stimulation in acupuncture research: pitfalls and challenges of 
heterogeneity. J Altern Complement Med; 21:113-28.

Ibrahim, I., Goddard, N., Khan W.S., Smitham, P. (2012). Carpal tunnel syndrome: a review of the recent literature. The Open Orthopaedics Journal.; Vol 6. Page 69-76

Jagga, V \& Lehri, A. (2011). Occupation and its association with carpal tunnel syndrome- a review. Journal of Exercise Science and Physiotherapy. Vol. 7, No. 2: 68-78.

Kaptchuk, T.J. (2004). Acupuncture: theory, efficacy, and practice ann intern Med 136 374-83

Kenji, K., Kaoru, O. (2014). Acupuncture therapy: mechanism of action, efficacy, and safety: a potential intervention for psychogenic disorders?. Biopsychosoc Med. 8: 4. [published online 2014 Jan 20] doi: 10.1186/1751-0759-8-4.

Langevin, H.M., Schnyer, R., MacPherson, H., Davis, R., Yumi, M., Hyungjun, K., Norman, K., Jieun K, Stephen C, Cristina M, Jessica, G., Claire, M. (2017). Rewiring the primary somatosensory cortex in carpal tunnel syndrome with acupuncture. Brain. Apr; 140(4): 914-927. Published online $2017 \quad$ Mar 2. doi: 10.1093/brain/awx015.

McCaig, C.D., Rajnicek, A.M., Song, B., Zhao, M. (2004). Has electrical growth cone guidance found its potential? Trends Neurosci. 25: 354359.

Napadow, V., Kettner, N., Liu, J., Li, M., Kwong, K.K., Vangel, M., et al. (2007). Hypothalamus and amygdala response to acupuncture stimuli in carpal tunnel syndrome. Pain. ; 130(3):254-66.
Permadi, G.P., Djuharto, S.S. (2004). Pedoman praktis belajar akupuntur dan akupuntur kecantikan. Bandung alumni.; 293-7.

Pecina M.M., et al. (2010). Carpal tunnel syndromes: Peripheral Nerve Compression Syndromes Third Edition. New York: CRC Press;

Saeid, K., Alireza, M., and Shila, H. (2012). Acupuncture in treatment of carpal tunnel syndrome: a randomized controlled trial study. J Res Med Sci.; January 17(1): 1-7

Tana L, et al. (2004). Carpal tunnel syndrome pada pekerja garmen di jakarta. Buletin Peneliti Kesehatan.. vol. 32, no. 2: 73-82.

Zijlstra, F.J., Berg-de, L.I., Huygen, F.J.P.M., Klein, J. (2004). Antiinflammatory actions of acupuncture. Mediators of Inflammation.; 12(2), 59-69. doi: $10.1080 / 0962935031000114943$ 